УДК658.272:625.27

JEL Classification: R 42

\title{
ОПТИМІЗАЦІЯ ЕКОЛОГІЧНИХ РИЗИКІВ ПРИ БУДІВНИЦТВІ ТА ЕКСПЛУАТАЦІЇ АВТОМОБІЛЬНИХ ДОРІГ
}

Юрченко О.В., канд. екон. наук, доцент

Сумський національний аграрний університет

Деділова Т.В., канд. екон. наук, доцент

Харківський національний автомобільно-дорожній університет

Постановка проблеми. Облік факторів ризику i невизначеності притаманний в тій чи іншій мірі будь-якій діяльності, проте їх вплив на кінцевий результат є різним. Ризик становить об'єктивно неминучий елемент прийняття будь-якого управлінського рішення в силу того, що невизначеність виступає невід'ємною характеристикою умов ведення виробництва.

Кожен вид господарської діяльності супроводжується ризиками. Специфіка діяльності підприємств дорожнього господарства зумовлюється особливостями дорожнього виробництва, що містять у собі частку ризику як об'єктивного, так і суб'єктивного походження. Зокрема, природні ризики дорожнього виробництва відносяться до об'єктивних та виникають в наслідок спонтанності природних процесів і явищ, стихійних лих. Також до об'єктивних ризиків можна віднести імовірнісний характер НТП, обмеженість і недостатність ресурсів тощо. Суб'єктивні ризики, притаманні дорожньому виробництву, $\epsilon$ наслідком випадковості, розбіжності в соціально-психологічних оцінках об'єкта дорожнього будівництва, зіткнення суперечливих інтересів держави та приватних осіб-замовників та ін.

Аналіз остатніх досліджень і публікацій. Проблематика ризику є досить актуальною, а іiі дослідженню присвячено праці багатьох іноземних та українських вчених. Так, зокрема, оцінку інвестиційних ризиків можна побачити в наукових працях нобелівських лауреатів Г. Марковіца [1] i В. Шарпа [2]. Питання управління підприємством у ризикових ситуаціях розглядали П. Бернстайн [3], В. Вітлінський [4], І. Дмитрієв [5], В. Лук'янова [6], Ф. Найт [7]. Теоретичні аспекти поняття ризику вивчають такі вчені, як С. Ілляшенко [8], Н. Коленда [9], В. Проскура [10], Н. Скопенко [11] та інші.

Невирішені складові загальної проблеми. Водночас аналіз останніх досліджень і публікацій з означеної теми засвідчив, що питання дослідження екологічних ризиків при будівництві та експлуатації автомобільних доріг в українській економічній науці залишаються недостатньо розглянутими. Зокрема, потребує особливої уваги напрями екологічного страхування автомобільних доріг України.

Формулювання цілей статті. Метою статі є обгрунтування та розробка теоретичних засад управління ризиками підприємств дорожнього господарства при будівництві та експлуатаційному утриманні автомобільних доріг 
загального користування на основі формування бази їх екологічного страхування.

Виклад основного матеріалу дослідження. Дорожнє господарство $є$ невід'ємною складовою економічного життя країни, оскільки виконує головну роль в своєчасному організаційному забезпеченні транспортних потоків, впливає на їх якість, підтримує належний стан технічного експлуатаційного стану автодоріг. Останній безпосередньо корелює 3 безпекою та якістю пасажирських i вантажних автомобільних перевезень, що, в свою чергу, обумовлює зміну темпів зростання сфери послуг, ринку зайнятості, автомобільного товарного ринку. На жаль, стан та розвиток сучасного дорожнього господарства як складової інфраструктурного потенціалу України залишається доволі низьким, не зважаючи на проведені реформи. Тому оцінка ризику, зокрема екологічного, аналіз причин його виникнення і масштабів прояву в конкретних ситуаціях, має важливе значення для оптимального функціонування дорожньої галузі.

За умов ринкових перетворень становлення інституту екологічного страхування автомобільних доріг повинне створюватися у певній послідовності (рис. 1.).

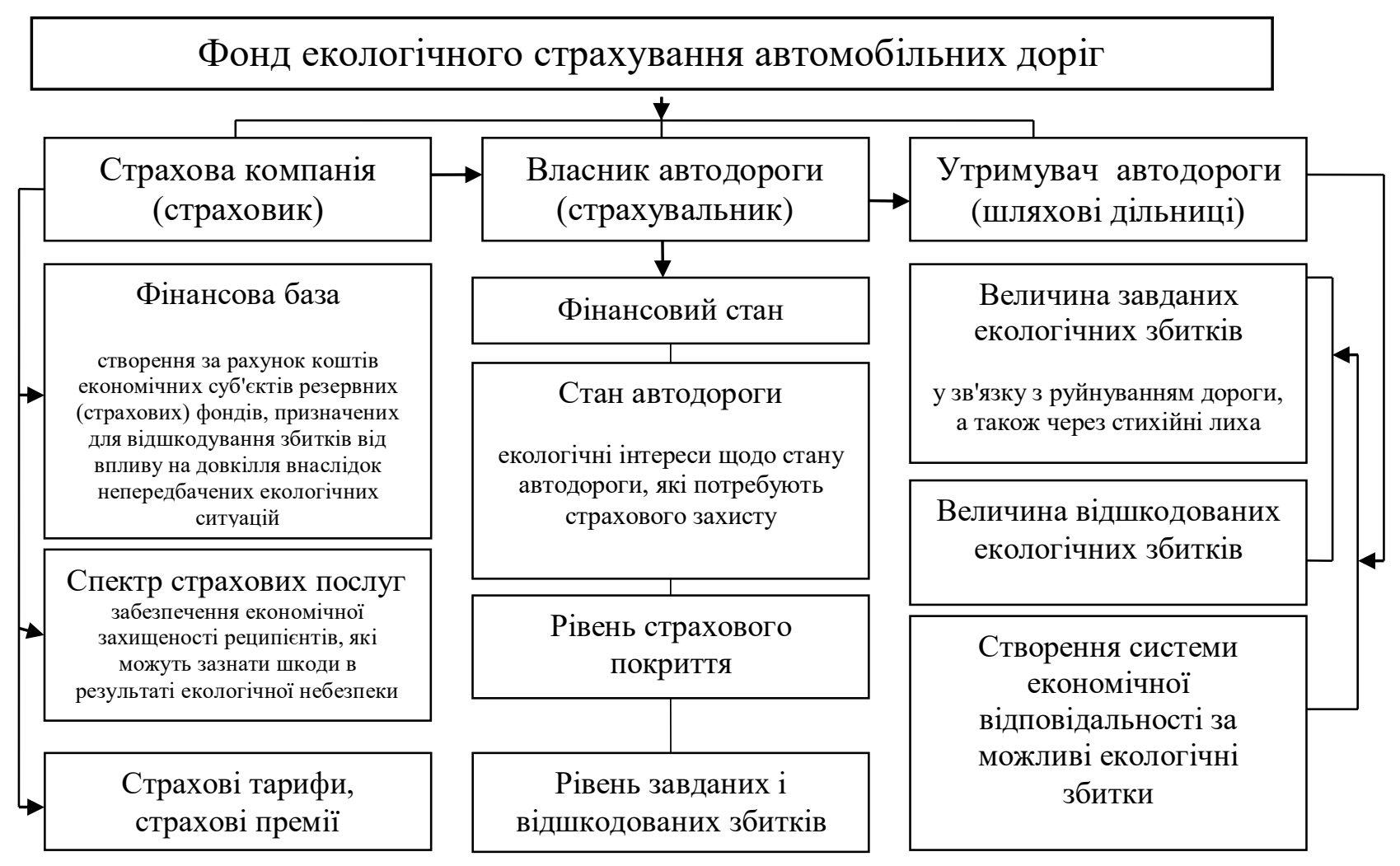

Рис. 1. Блок-схема формування бази екологічного страхування автодоріг Джерело: розробка авторів 
Основу пропонованої системи екологічного страхування формують: інформаційна база даних про кількість укладених договорів та страхові суми; інформаційна база даних про види ризиків, частоту страхових випадків та заявлені страхові випадки; інформаційна база даних про обсяги та структуру інвестицій у розвиток дорожнього господарства; інформаційна база даних та відповідних нормативів природоохоронного, податкового i страхового характеру. За результатами цих даних здійснюється прийняття рішення про страхову компенсацію розміру реальних збитків, які завдаються дорозі, яка не може перевищувати рівень екологічних збитків, але й не повинна бути нижчою величини збитку $[12,13]$. Впровадження методики оцінки ризиків внаслідок настання ризиків екологічної небезпеки потребує обчислення страхових тарифів відповідно до визначеного рівня ризику. За цих умов саме екологічне страхування є механізмом, здатним подолати такі наслідки таких екологічних проблем, як рівень зносу основних фондів підприємств автомобільного транспорту, недосконале державне управління в сфері забезпечення охорони навколишнього середовища та функціонування дорожнього господарства, недотримання екологічного законодавства 3 боку суб'єктів підприємницької діяльності та відсутність чіткого розмежування природоохоронних та господарських функцій, недостатнє усвідомлення пріоритетів сталого розвитку суспільства з боку громадян та державних органів влади і самоуправління.

В дорожньому господарстві система еколого-економічних ризиків невід'ємна від процесу ведення дорожніх робіт. Відсутність ефективної системи контролю за якістю виконання дорожньо-будівельних та ремонтних робіт на державному рівні веде до масових порушень технологій дорожнього виробництва, поширення недоліків експлуатаційного утримання автомобільних доріг, зокрема обумовлює недостатній рівень підготовки земляного полотна та штучних споруд до зимового утримання, низьку якість ямкового ремонту, несвоєчасність ліквідації деформацій покриття, відсутність поверхневого водовідводу з верхньої частини земляного полотна тощо.

Існуюча система контролю якості дорожніх робіт в Україні неефективна $\mathrm{i}$ потребує докорінного реформування під час реалізації реформи системи управління дорожньою галуззю України. Розвиток системи управління станом дорожніх покриттів, поширення діагностичних досліджень доріг та штучних споруд, впровадження системи управління якістю та удосконалення лабораторної бази дорожніх підприємств, а також активне залучення громадськості до здійснення контролю за якістю будівельних робіт та станом доріг повинні стати невід'ємними складовими нової системи контролю якості дорожніх робіт [14].

Реформування дорожньої галузі неможливе без запровадження нових механізмів фінансування дорожнього будівництва. Отримання максимально достовірної та об'єктивної інформації щодо вартості дорожніх робіт є головною задачею в системі ціноутворення в дорожній галузі. Тому запорукою 
ефективного використання бюджетних коштів та оптимізації грошових потоків в дорожній галузі є удосконалення системи кошторисного ціноутворення.

Фактична потреба у фінансуванні дорожньої галузі в Україні значно перевищує поточні показники відповідних видатків держбюджету України у 2018 р. Так, в сучасних умовах заміни дорожнього покриття потребують майже всі 169,5 тис. км доріг загального користування, для чого за оцінками експертів потрібно витратити не менше 450 млрд. грн. Розбудова мережі автомобільних шляхів та забезпечення ії якості відповідно до міжнародних стандартів вимагає значних фінансових ресурсів.

Для виконання означених цілей в Програмі діяльності Кабінету Міністрів України та Стратегії сталого розвитку «Україна-2020» для дорожньої галузі визначено такі завдання:

- передача доріг місцевого значення до сфери управління обласних державних адміністрацій з одночасною передачею джерел фінансових ресурсів, необхідних для виконання відповідних функцій та розмежування функцій замовника та виконавця будівництва, ремонту та утримання доріг шляхом створення на базі ВАТ «ДАК «Автомобільні дороги України» регіональних компаній та їх подальшої приватизації;

- створення конкурентного середовища в дорожній галузі для реалізації проектів державно-приватного партнерства; включення до контрактів на будівництво автомобільних доріг обов'язкової умови про взяття підрядником зобов'язань із забезпечення гарантійного терміну служби елементів автомобільної дороги з обов'язком оприлюднення відповідних умов контрактів, про підтримку після введення в експлуатацію та відповідальність за невиконання цих положень;

- запровадження контрактів на експлуатаційне утримання автодоріг тривалого строку дії (5-7 років);

- забезпечення їх новою системою кількісних показників для оцінки результатів роботи підрядника, що корелює з рівнем екологічної безпеки та споживчими якостями автодоріг;

- здійснення з боку держави ефективного контролю за дотриманням норм вагового навантаження для доріг загального користування i місцевих доріг, у тому числі і з застосуванням систем автоматизованого контролю та введенням сезонних обмежень;

- впровадження європейських стандартів будівництва, ремонту та утримання доріг із використанням конкурентоздатних та перспективних вітчизняних матеріалів та технологій, перехід на планово-попереджувальну стратегію утримання автодоріг;

- вдосконалення системи оплати за проїзд по дорогах великовагового транспорту (повна маса 12 т і вище) та визначення механізмів спрямування залучених коштів на утримання, ремонт і будівництво доріг [12]. 
Гострий дефіцит бюджетних коштів зумовлює пошук альтернативних джерел фінансування природоохоронних заходів у дорожньому господарстві, спрямованих на підтримку екологічної безпеки в транспортно-дорожньому комплексі України. Тому створення цільового страхового дорожнього фонду, як одного 3 можливих джерел фінансування, допоможе передбачити максимальну кількість ризиків, що можуть виникнути у процесі реалізації проекту відновлення і розвитку дорожнього господарства.

Висновки $з$ проведеного дослідження. Прибутковість проектів розвитку та уникнення будь-якої форми ризику в значній мірі залежить від ринкових факторів та має тенденцію варіюватися, що може призвести до неможливості компенсації понесених витрат або передчасного припинення проекту. Відповідальність держави залишається i умови ведення конкретної господарської діяльності (в нашому випадку, виконання дорожніх робіт) можуть бути більш політично або соціально складним для впровадження.

Для розвитку дорожнього господарства (при мінімізації усіх видів ризику) необхідне: визначення пріоритетних напрямів для першочергового залучення приватних інвестицій; спрощення процедур оформлення прав користування земельними ділянками для будівництва доріг; розробка механізму фінансування проектів будівництва та експлуатації дорожньої мережі країни; вирішення дискусійних питань та затвердження принципів функціонування платних доріг; забезпечення належного вагового контролю на дорогах для уникнення передчасного їх руйнування.

За цих умов формування фонду екологічного страхування автомобільних доріг може стати дієвим механізмом оптимізація екологічних ризиків при будівництві та експлуатації автомобільних доріг в нашій країні.

\section{Перелік посилань}

1. Harry Markowitz. Portfolio Selection. The Journal of Finance. 1952. Vol. 7, No. 1. P. 77-91.

2. William F. Sharpe, Gordon J. Alexander, Jeffrey Bailey. Fundamentals of Investments. Prentice-Hall, 2000. $816 \mathrm{p}$.

3. Бернстайн П. Против богов: укрощение риска. М. : Олимп-Бизнес, 2000. $400 \mathrm{c}$.

4. Вітлінський В. В., Великоіваненко Г. І. Ризикологія в економіці та підприємництві. К. : КНЕУ, 2004. 480 с.

5. Дмитрісв І. А., Нестеренко В. Ю. Управління ризиком рейдерського захоплення підприємства: монографія. Х.: Харк. нац. автомоб.-дор. ун-т., 2011. $163 \mathrm{c}$.

6. Лук'янова В. В., Свідерська А. В. Процедури управління ризиками як складова системи управління зовнішньоекономічною діяльністю підприємства. Науковий вісник Полісся. 2015. № 3 (3). С. 90-95. : сайт. URL : http://journals.uran.ua/nvp chntu/article/view/60706/56445 (дата звернення : 01.05.2019). 
7. Найт Ф. Риск, неопределенность и прибыль. М. : Дело, 2003. 360 с.

8. Ілляшенко С. М. Економічний ризик: Навчальний посібник. 2-ге вид., доп. перероб. К.: Центр навчальної літератури, 2004. 220 с.

9. Коленда Н. В. Стратегічний підхід до управління ризиками підприємства в умовах забезпечення його соціо-еколого-економічної безпеки. Економіка $i$ суспільство. 2018. Випуск 15. С. 333-337. : сайт. URL : http://www.economyandsociety.in.ua/journal/15_ukr/52.pdf (дата звернення : 01.05.2019).

10. Проскура В. Ф., Білак Р. Г. Методологічні підходи до управління ризиками. Економіка і суспільство. 2017. Випуск 9. С. 599-607 : сайт. URL : http://www.economyandsociety.in.ua/journal/9 ukr/102.pdf (дата звернення : 01.05.2019).

11. Скопенко Н. С., Свсєєва. І. В., Москаленко В. О. Управління ризиками в проектному менеджменті : сайт. URL : http://www.investplan.com.ua/pdf/24_2013/11.pdf (дата звернення 01.05.2019).

12. План заходів Міністерства інфраструктури України 3 виконання Програми діяльності КМУ, Стратегії сталого розвитку «Україна - 2020» та Коаліційної угоди у 2015 році : сайт. URL : http://mtu.gov.ua/uk/show/road_area.html (дата звернення 01.05.2019).

13. Доброноженко О. В., Несвєтов О. О. Проблеми управління екологоекономічними ризиками на підприємствах будівельної індустрії. Вісник CHAУ. Розділ «Економіка та менеджмент». 2009. № 12 (38). С. 116-120.

14. Доброноженко О. В., Несвєтов О. О. Еколого-економічна оцінка функціонування дорожнього господарства. Вісник СНАУ. Розділ «Будівниитво». 2013. № 8 (17). С. 99-102.

\section{References}

1. Harry, Markowitz (1952), Portfolio Selection, The Journal of Finance, Vol. 7, No. 1. P. 77-91.

2. William, F. Sharpe, Gordon, J. Alexander, Jeffrey, Bailey (2000), Fundamentals of Investments. Prentice-Hall. $816 \mathrm{p}$.

3. Bernstein, P. (2000), Against the gods: Taming the risk [Protyv bohov: ukroshchenye ryska], Olympus Business, Moscow, $400 \mathrm{p}$.

4. Vitsinsky, V. V., Velikoivanenko, G. I. (2004), Riskology in Economics and Entrepreneurship [Ryzykolohiya $v$ ekonomitsi ta pidpryyemnytstvi], KNEU, Kiev, $480 \mathrm{p}$.

5. Dmitriev, I. A., Nesterenko, V. Yu. (2011), Risk management of the raider capture of the enterprise: a monograph Dmitriev I. A., Nesterenko V. Yu. Risk management of the raider capture of the enterprise: a monograph. [Upravlinnya ryzykom reyders'koho zakhoplennya pidpryyemstva: monohrafiya], KHNAHU, Kharkiv, 163 p.

6. Lukyanova, V. V., Sviderska, A. V. (2015), "Risk management procedures as a component of the system of management of foreign economic activity of the 
enterprise" ["Protsedury upravlinnya ryzykamy yak skladova systemy upravlinnya zovnishn'oekonomichnoyu diyal'nistyu pidpryyemstva"], Scientific bulletin Polesie, No. 3 (3), $\quad$ P. $90-95, \quad$ available at http://journals.uran.ua/nvp_chntu/article/view/60706/56445 (last accessed 01.05.2019).

7. Knight, F. (2003), Risk, uncertainty and profit [Risk, neopredelennost' $i$ pribyl'], Delo, М.: Дело, Moscow, 360 p.

8. Illyashenko, S. M. (2004), Economic risk: a study guide. 2nd ed. [Ekonomichnyy ryzyk: Navchal'nyy posibnyk. 2-he vyd., dop. pererob.], Center for Educational Literature, Kiev, 220 p.

9. Kolenda, N. A. (2018), "Strategic Approach to Enterprise Risk Management in Conditions of Ensuring Its Socio-Ecological-Economic Security ["Stratehichnyy pidkhid do upravlinnya ryzykamy pidpryyemstva v umovakh zabezpechennya yoho sotsio-ekoloho-ekonomichnoyi bezpeky"], Economics and Society, Issue 15, P. 333-337, available at : http://www.economyandsociety.in.ua/journal/15_eng/52.pdf (last accessed 01.05.2019).

10. Proskura, V. F., Bilak, R. G. (2017), "Methodological approaches to risk management" ["Metodolohichni pidkhody do upravlinnya ryzykamy"], Economics and Society, Issue 9, P. 599-607, available at : http://www.economyandsociety.in.ua/journal/9_ukr/102.pdf (last accessed 01.05.2019).

11. Skopenko, N. S., Yevseyev, I. V., Moskalenko, V. O. , "Risk management in project management" ["Upravlinnya ryzykamy v proektnomu menedzhment"], available at : http://www.investplan.com.ua/pdf/24_2013/11.pdf (last accessed 01.05.2019).

12. "Action Plan of the Ministry of Infrastructure of Ukraine on the implementation of the Program of Activities of the Cabinet of Ministers of Ukraine, the Strategy of Sustainable Development "Ukraine 2020" and the Coalition Agreement in 2015" ["Plan zakhodiv Ministerstva infrastruktury Ukrayiny z vykonannya Prohramy diyal'nosti KMU, Stratehiyi staloho rozvytku «Ukrayina $2020 »$ ta Koalitsiynoyi uhody u 2015 rotsi"], available at : http://mtu.gov.ua/en/show/road_area.html (last accessed 01.05.2019).

13. Dobronozhenko, O. V., Nesvetov, O. O. (2009), "Problems of management of ecological and economic risks at the enterprises of the construction industry" ["Problemy upravlinnya ekoloho-ekonomichnymy ryzykamy na pidpryyemstvakh budivel'noyi industriyi"], Bulletin of Sumy national agrarian University. Section "Economics and management", No. 12 (38), P. 116-120.

14. Dobronozhenko, O. V., Nesvetov, O. O. (2013), "Ecological and economic evaluation of the road economy" ["Ekoloho-ekonomichna otsinka funktsionuvannya dorozhn'oho hospodarstva"], Bulletin of Sumy national agrarian University. Section "Construction", No 8 (17), P. 99-102. 


\section{РЕФЕРАТИ РЕФЕРАТЫ ABSTRACTS}

\section{УДК658.272:625.27; JEL: R 42}

\section{Юрченко О.В., Деділова Т.В. ОПТИМІЗАЦІЯ ЕКОЛОГІЧНИХ РИЗИКІВ ПРИ БУДІВНИЦТВІ ТА ЕКСПЛУАТАЦІї АВТОМОБІЛЬНИХ ДОРІГ}

Mema. Метою статі є обгрунтування та розробка теоретичних засад управління ризиками підприємств дорожнього господарства при будівництві та експлуатаційному утриманні автомобільних доріг загального користування на основі формування бази їх екологічного страхування. Методика дослідження. В роботі використано наступні методи: діалектичний метод (при виявленні причинно-наслідкового зв'язку економічних i екологічних процесів в дорожньому виробництві); аналітичний метод (для систематизації інформації щодо формування бази екологічного страхування автодоріг); спостереження та узагальнення (для розробки рекомендацій щодо напрямів розвитку дорожнього господарства). Результати. В дослідженні розглянуто актуальні теоретичні питання оптимізації екологічних ризиків при будівництві та експлуатації автомобільних доріг. Встановлено зв'язок між системою еколого-економічних ризиків та процесом виробництва дорожніх робіт, що опосередковується через систему контролю за якістю виконання дорожньо-будівельних та ремонтних робіт. Розроблено блок-схему формування бази екологічного страхування автодоріг, що містить детальні рекомендації зі створення цільового фонду екологічного страхування автомобільних доріг. Наголошено на важливості створення такого фонду як дієвого механізму оптимізація екологічних ризиків при будівництві та експлуатації автомобільних доріг в Україні. Наукова новизна. Отримав подальший розвиток теоретико-методичний підхід до управління ризиками в дорожньому господарстві шляхом розробки блок-схеми формування бази екологічного страхування автодоріг, спрямованої на деталізацію структури цільового фонду екологічного страхування вітчизняних автошляхів. Практична значущість. Результати дослідження можуть слугувати методичними рекомендаціями органам державного управління при розробці регіональних програм 3 будівництва та експлуатації автодоріг, розвитку транспортної мережі регіону.

Ключові слова: дорожне господарство, автомобільна дорога, екологічні ризики, страхування, фонд, управління.

УДК658.272:625.27; JEL: R 42

Юрченко О.В., Дедилова Т.В. ОПТИМИЗАЦИЯ ЭКОЛОГИЧЕСКИХ РИСКОВ ПРИ СТРОИТЕЛЬСТВЕ И ЭКСПЛУАТАЦИИ АВТОМОБИЛЬНЫХ ДОРОГ

Цель. Целью статьи является обоснование и разработка теоретических основ управления рисками предприятий дорожного хозяйства при 
строительстве и эксплуатационном содержании автомобильных дорог общего пользования на основе формирования базы их экологического страхования. Методика исследования. В работе использованы следующие методы: диалектический метод (при выявлении причинно-следственной связи экономических и экологических процессов в дорожном производстве); аналитический метод (для систематизации информации для формирования базы экологического страхования автодорог), наблюдения и обобщения (для разработки рекомендаций по направлениям развития дорожного хозяйства). Результаты. В исследовании рассмотрены актуальные теоретические вопросы оптимизации экологических рисков при строительстве и эксплуатации автомобильных дорог. Установлена взаимосвязь между системой экологоэкономических рисков и процессом производства дорожных работ, которая опосредуется через систему контроля качества выполнения дорожностроительных и ремонтных работ. Разработана блок-схема формирования базы экологического страхования автодорог, содержащая подробные рекомендации по созданию целевого фонда экологического страхования автомобильных дорог. Подчеркнута важность создания такого фонда как действенного механизма оптимизация экологических рисков при строительстве и эксплуатации автомобильных дорог в Украине. Научная новизна. Получил дальнейшее развитие теоретико-методический подход к управлению рисками в дорожном хозяйстве путем разработки блок-схемы формирования базы экологического страхования автодорог, направленной на детализацию структуры целевого фонда экологического страхования отечественных автомобльных дорог. Практическая значимость. Результаты исследования могут служить методическими рекомендациями органам государственного управления при разработке региональных программ по строительству и эксплуатации автодорог, развития транспортной сети региона.

Ключевые слова: дорожное хозяйство, автомобильная дорога экологические риски, страхование, фонд, управление.

\section{UDC 658.272:625.27; JEL: R 42}

Yurchenko O., Dedilova T. OPTIMIZATION OF ENVIRONMENTAL RISKS DURING THE CONSTRUCTION AND OPERATION MAINTENANCE OF HIGHWAYS

Purpose. The purpose of the article is to substantiate and develop the theoretical principles of risk management of road economy enterprises during the construction and operation maintenance of highways on the basis of the formation of their ecological insurance base. Methodology of research. The following methods were used in the research. The dialectical method was used for identifying causal link of economic and environmental processes in road production. The analytical method was applied for systematization of information for the formation of the base of environmental insurance of highways. The observation and generalization were 
relevance for the development of recommendations for the directions of development of the road economy. Findings. The research considers actual theoretical questions of optimization of environmental risks during the construction and operation maintenance of highways. The connection between the system of ecological and economic risks and the process of production of road works, which is mediated through a system of control over the quality of road construction and maintenance work, was established. The block diagram of the formation of the base of the ecological insurance of highways has been developed, which contains detailed recommendations for the formation of a trust fund for ecological insurance of highways. The importance of creating such a fund as an effective mechanism to optimize ecological risks in the construction and operation maintenance of roads in Ukraine was underlined. Originality. The theoretical and methodological approach to risk management in road economy was further developed by formation of block diagram base of the ecological insurance of highways, aimed at detailing the structure of the fund of ecological insurance of domestic roads. Practical value. The results of the research can be used as guidelines for the public administration in the development of regional programs for the construction and operation maintenance of highways, development of transport network of the region.

Key words: road economy, highways, ecological risks, insurance, fund, management.

\section{Відомості про авторів / Сведения об авторах / About the Authors}

Юрченко Оксана Вікторівна - кандидат економічних наук, Сумський національний аграрний університет, доцент кафедри будівельного виробництва, м. Суми, Україна; e-mail: vitaboris1979@ukr.net. Моб. 066-716-76-80.

Юрченко Оксана Викторовна - кандидат экономических наук, Сумской национальный аграрный университет, доцент кафедры строительного производства, г. Сумы, Украина.

Yurchenko Oksana - Candidate of Science (Economics), Sumy National Agrarian University, Associate Professor at the Department of Construction, Sumy, Ukraine.

Деділова Тетяна Вікторівна - кандидат економічних наук, доцент, Харківський національний автомобільно-дорожній університет, доцент кафедри економіки і підприємництва, м. Харків, Україна; e-mail: dedilova @ukr.net; ORCID ID: https://orcid.org/0000-0002-3924-979X. Моб. 050-281-83-28.

Дедилова Татьяна Викторовна - кандидат экономических наук, доцент, Харьковский национальный автомобильно-дорожный университет, доцент кафедры экономики и предпринимательства, г. Харьков, Украина.

Dedilova Tetiana - Candidate of Science (Economics), Associate Professor, Kharkiv National Automobile and Highway University, Associate Professor at the Department of Economics and Entrepreneurship, Kharkiv, Ukraine. 